\title{
The roles and strategies of ASEAN in the Belt and Road Initiative (BRI)
}

\author{
El papel y las estrategias de la ASEAN \\ en la Iniciativa de la Franja y la Ruta (IFR)
}

\author{
Sang Chul Park \\ Professor at Graduate School of Knowledge based Technology and Energy. \\ Korea Polytechnic University \\ scpark@kpu.ac.kr
}

Summary: I. Introduction.-II. Theoretical background.-III. Roles and strategies of ASEAN and China with the BRI. III.I. ASEAN's roles and strategies for the BRI. III.II. Chinese role and strategies of the BRI. III.III. Financing and risks of the BRI in participating countries.IV. Analysis on the BRI and possible impacts of the COVID-19 pandemic on the BRI. IV.I. The BRI in ASEAN and China. IV.II. Possible impacts of the COVID-19 pandemic on the BRI.-V. Conclusion.

\begin{abstract}
Under the Belt and Road Initiative (BRI), China focuses on the ASEAN as part of land bridge connecting China to Southeast Asia, the Indian Ocean, and the China-Indochina Peninsula Corridor sea route that is the comprehensive sea route between China, South China Sea, Indian Ocean, and Europe. On the other hand, ASEAN member nations regard the BRI as an avenue to improve connectivity with their poor infrastructure development which will generate trade and investment increase in the region particularly through improved logistics. Accordingly, ASEAN member nations are keen to develop their infrastructure projects in collaboration with Chinese companies and funding agencies mainly in the forms of joint venture. The Asian Development Bank (ADB) estimates that the total infrastructure investment needs in the ASEAN from 2016 to 2030 will be between USD 2.8 trillion with baseline estimate to USD 3.1 trillion with climate adjusted estimate. This paper aims to argue how China and the ASEAN can be interacted by the BRI and what are impacts of the BRI on the region. Furthermore, it analyzes which roles do the BRI play in building the region between China and the ASEAN member nations. Last, but not least, it also focuses on Chinese national strategy how to implement the BRI in the region.
\end{abstract}

Keywords: BRI, trade and investment, regional integration, economic growth, development strategy, COVID-19 pandemic. 
Resumen: Mediante la Iniciativa Franja y Ruta (IFR), China centra su atención en la ASEAN como parte del puente terrestre que conecta China con el sudeste asiático, el Océano Índico y la ruta marítima del corredor entre China y la península de Indochina, que constituye la vía marítima integral más amplia entre China y el Mar del Sur de China, el Océano Índico y Europa. Por otra parte, los países miembros de la ASEAN consideran la IFR como una vía para mejorar la conectividad, dado su pobre desarrollo en infraestructuras, lo que generará un aumento del comercio y de la inversión en la región, principalmente a través de una mejor logística. En consecuencia, los países miembros de la ASEAN están interesados en desarrollar sus proyectos de infraestructura en colaboración con empresas y agencias de financiación chinas, principalmente mediante la constitución de empresas conjuntas. El Banco Asiático de Desarrollo (BAD) estima que las necesidades totales de inversión en infraestructura en los países ASEAN, entre 2016 y 2030, se situarán en torno a USD 2,8 billones como estimación de referencia, y USD 3,1 billones como estimación ajustada al clima. Este artículo analiza las posibles interacciones entre China y la ASEAN en el marco de la IFR y su posible impacto en la región. Además, analiza el papel que la IFR puede jugar en la creación de la región entre China y los países miembros de la ASEAN. Por último, pero no menos importante, también se centra en la estrategia nacional china sobre cómo implementar la IFR en la región.

Palabras clave: IFR, comercio e inversión, integración regional, crecimiento económico, estrategia de desarrollo, pandemia COVID-19. 


\section{Introduction}

In 2013, Chinese government launched the new silk-road project known as One Belt and One Road that turned to the Belt and Road Initiative (BRI) in $2018^{1}$. President Xi Jinping initially regarded the BRI as the project of $21^{\text {st }}$ Century that has assumed enormous importance. It is a major global project bolstering to close a large infrastructure gap constraining trade, openness and prosperity. China and other economies have signed cooperation agreements that have been rising as a share of the world economy. The BRI development strategy aims to build connectivity and cooperation across six main economic corridors encompassing China and Indian subcontinent, and Indochina. Asia needs USD 26 trillion in infrastructure investment to 2030 , including climate related needs ${ }^{2}$.

Chinese government expects that its investment in building infrastructure generates positive impacts on countries involved. Mutual benefits among all participating countries in the BRI are a core feature of the BRI, which will support to develop markets for China's products in the long term and to alleviate industrial excess capacity in the short term. The BRI set the priority to build hardware-oriented infrastructure such as power, transport, telecommunication, and water and sanitation. It is supervised by the leading group of the National Development and Reform Commission (NDRC) coordinating all projects including inter alia with the Ministry of Commerce (MOFCOM), the Ministry of Foreign Affairs (MFA), and the Development Research Center of the State Council (DRC).

BRI investment projects are estimated to over USD 1 trillion of outward funding for foreign infrastructure over the 10-year period from 2017. In order to finance the BRI, Chinese government formed the Silk Road Fund (SRF) supported by state-directed development and commercial banks. Additionally, China has approached to international investment including multilateral development banks as well as private and public partnerships ${ }^{3}$. The BRI has geopolitical goals associated in linking of its neighbors economically more closely to China. At the same time, China regards the BRI as a long term economic strategy focusing on the economic aspects of the initiative for itself and other participating economies, both those in the Asian region and beyond ${ }^{4}$.

${ }^{1}$ OECD, China's Belt and Road Initiative in the Global Trade, Investment and Finance Landscape, OECD Business and Finance Outlook (Paris: OECD, 2018).

2 Asia Development Bank, Meeting Asia's Infrastructure Needs (Manila: Asia Development Bank, 2017), www.adb.org/sites/default/files/publication/227496/special-report-infrastructure.pdf

${ }_{3}$ PwC, China's New Silk Route: The Long and Winding Road (London: PwC, 2016), https://www.pwc.com/gx/en/growth-markets-center/assets/pdf/china-new-silk-route.pdf

${ }^{4}$ OECD, op. cit. (2018). 
President Xi announced that China would actively promote international co-operation through the Belt and Road Initiative ${ }^{5}$. In doing so, it will achieve policy, infrastructure, trade, financial, and people-to-people connectivity and thus build a new platform for international co-operation to create new drivers of shared development. Furthermore, the BRI involves education, cultural and scientific exchanges to help other countries learn from China's development experience. For it, China has launched the Centre for International Knowledge on Development and China's National Plan on Implementation of the 2030 Agenda for Sustainable Development along with other related initiatives ${ }^{6}$.

Chinese government strongly intends to implement the comprehensive strategy of building a moderately prosperous society in all aspects that deepens reforms and advances the law-based governance of China. At the same time, it strengthens the Communist Party self-conducted and seeks coordinated development in the economic, political, cultural, social, and ecological fields by launching the BRI that is based on the guidance of the development concept for innovative, green, open and shared development.

Under the BRI, China regards ASEAN as a part of the land bridge connecting China to Southeast Asia, South Asia, the Indian Ocean, and the China-Indochina Peninsula Corridor sea route that connects China, South China Sea, Indian Ocean, and Europe. ASEAN member nations also see the BRI as a great opportunity to improve connectivity with infrastructure development that will eventually increase trade and investment in the region through improved logistics. Accordingly, ASEAN member nations are ready to develop infrastructure projects in cooperation with Chinese construction companies and financing agencies mainly through joint ventures ${ }^{7}$.

This paper focuses on the strategies of ASEAN and China how the both parties could be interacted through the BRI. Furthermore, it investigates which roles can the BRI play in creating a region building in Southeast Asia particularly in ASEAN. Last, but not least, it also analyzes whether

${ }^{5} \mathrm{Xi}$, J. P., Secure a Decisive Victory in Building a Moderately Prosperous Society in all Respects and Strive for the Great Success of Socialism with Chinese Characteristics for a New Era, Delivered at the 19th National Congress of the Communist Party of China, 18 October 2017.

${ }^{6}$ Chinese Government, China's National Plan on Implementation of the 2030 Agenda for Sustainable Development (Beijing: Chinese Government, 2016), www.fmprc.gov.cn/ web/ziliao_674904/zt_674979/dnzt_674981/qtzt/2030kcxfzyc_686343/P02017041468 9023442403.pdf

7 Jusoh, S., The Impact of BRI on Trade and Investment in ASEAN, in CIMB ASEAN Research Institute (ed.) China's Belt and Road Initiative (BRI) and Southeast Asia (Kuala Lumpur: CIMB CARI,2018), 10-18. 
ASEAN and the BRI could generate win-win processes in terms of trade, investment, and economic growth in the region or not. To the last, it forecasts how the COVID-19 pandemic affects the BRI in ASEAN. To find answers to these questions, critical analysis of literature, inference and statistical data analysis are employed.

\section{Theoretical background}

The East Asian approach on the economic integration and regional cooperation processes differs from the European model. The East Asian regionalism has not been driven by inside, but outside. It can be characterized as loose economic cooperation and informal, consensus based, no legal binding, and high reluctance to engage political integration and multilateral security cooperation. Even ASEAN as the only one formalized institution as an economic common market since 2015 in East Asia prefers to national interest, state sovereignty, and equality among the member states.

In terms of regional economic integration process, the EU adopted Balasa's approach, on which is composed of five steps such as free trade agreement, tariff union, common market, economic union, and political union $^{8}$. The political union is the last phase, and the regional integration process is fully completed and becomes a united nation. At present, the EU is in the fourth stage and heading for the political union in the future although there are many struggles remained and no one knows exactly when it will be completed.

Compared with Europe, East Asia is under-institutionalized until now except ASEAN, although there are multilateral economic cooperation formats between ASEAN and the three major East Asian economies such as China, Japan, and South Korea in the names of ASEAN Plus Three or ASEAN Plus One. However, creating regional institutionalization in East Asia is not new. Contrary to the single institution oriented approach in Europe, East Asia has searched for a number of regional institutions that could deal effectively with various regional issues ${ }^{9}$. As such, multiple institutions without systemic linkages may continue to increase in the region ${ }^{10}$. There are other explanations about East Asian approaches, which are

${ }^{8}$ Balassa, B. Towards a Theory of Economic Integration, International Review for Social Sciences, 14:1 (1961): 1-17.

9 Pempel, T. J. Soft Balancing, Hedging, and Institutional Darwinism: The Economic Security Nexus and East Asian Regionalism, Journal of East Asian Studies, 10 (2010): 209-238.

${ }_{10}$ Zhao, S., Soft versus Structural Regionalism: Organizational Forms of Cooperation in Asia Pacific, The Journal of East Asian Affairs, 12:1 (1998): 96-134. 
unforeseen nature of regional institutionalization representing regionalization instead of creating regionalism. These point out that East Asian institutions have evolved in decentralized, contradictory, and ad hoc ways instead of deepening and solidifying regionalism in Europe. It is rather soft regionalism or informal regionalism ${ }^{11}$.

On the contrary, it is also fully possible that East Asian regionalism anticipates that the evolutionary dynamics of institutionalizing East Asia will take place in coming decades because East Asian countries' turn to bilateral FTAs shows their increasing interests in institutional engagement. In fact, a number of bilateral FTAs completed in the 2000s created a lattice regionalism in East Asia that will ultimately take from bi-lateral to plurilateral and regional path toward institutionalization. By time, several bilateral FTAs will turn to region-wide FTAs without any regional center because interlocking and overlapping FTAs generate inevitably high transaction costs ${ }^{12}$.

In fact, East Asian countries joined multiple institutions whose memberships overlap with each other because they were not able to develop a core regional institution being the basis for regional integration and cooperation in terms of economy and politics. Moreover, regional institutions in East Asia have developed in the areas of individual issue without creating systematic linkages ${ }^{13}$. As a result, there is no regional institution that deals with economies, politics, and security comprehensively in the whole region ${ }^{14}$.

Accordingly, the theory of plurilateral and regional path toward institutionalization in East Asia is adopted to explain East Asian economic integration processes particularly focusing on ASEAN and the BRI in this study. The reason for it is that the plurilateral theory can explain East Asian dynamic economic development more comprehensive than the theories of soft regionalism or informal regionalism.

${ }^{11}$ Katzenstein, P., Introduction: Asian Regionalism in Comparative Perspective, in Katzenstein, P. \&Shiraishi, T. (eds.) Network Power: Japan and Asia (Ithaca: Cornell University Press, 1997), 1-46.

12 Dent, C.-M., Networking the Region? The Emergence and Impact of Asia Pacific Bilateral Free Trade Agreement Projects, The Pacific Review, 16:1 (2003): 1-28.

${ }^{13}$ Katzenstein, P., A world of Regions: Asia and Europe in the American Imperium (Ithaca: Cornell University Press, 2005).

14 Pempel, T. J., Regional Institutions and the Economy-Security Nexus, in The Economy Security Nexus in Northeast Asia, Pempel, T. J. (ed.) (London: Routledge, 2013): 146163. 


\section{Roles and strategies of ASEAN and China with the BRI}

\section{III.I. ASEAN's roles and strategies for the BRI}

Association of South East Asian Nations (ASEAN) established in 1967 with the signing of the ASEAN Declaration known as the Bangkok Declaration expanded from its founding fathers, such as Indonesia, Malaysia, the Philippines, Singapore and Thailand to 10 member nations by including Cambodia in 1999. It mainly aims to accelerate the economic growth, social progress, and cultural development in the region through joint endeavors in the spirit of equality and partnership. In their roles and relations with one another, ASEAN has adopted several fundamental principles in the Treaty of Amity and Cooperation in Southeast Asia (TAC) in 1976. One of the fundamental principles is mutual respect for the independence, sovereignty, equality, and territorial integrity of all member nations.

At the $9^{\text {th }}$ ASEAN Summit in 2003, the ASEAN leaders resolved to establish an ASEAN community and affirmed their strong commitment to accelerate the establishment of an ASEAN community by 2015. They signed the CEBU Declaration on the Acceleration of the Establishment of an ASEAN Community by 2015 in the $12^{\text {th }}$ ASEAN Summit in 2007 . The ASEAN Community is composed of the three pillars such as the ASEAN Political-Security Community, ASEAN Economic Community, and ASEAN Socio-Cultural Community. Each pillar has its own blueprint and forms its roadmap for the ASEAN Community. Furthermore, ASEAN leaders, at the $30^{\text {th }}$ Anniversary of ASEAN in 2017, adopted the ASEAN Vision 2020, which agreed on shared vision of ASEAN as concert of member nations, outward looking, living in peace, stability and prosperity, close partnership in dynamic development and in a community of caring societies ${ }^{15}$.

In order to develop political, economic, and cultural cooperation within ASEAN member nations, ASEAN requires improved infrastructure to generate economic growth through increased trade, investment, competitiveness, and connectivity not only in the region but also with the rest of the world. The improved infrastructure development is very significant to increase the amount of ASEAN trade, inflow of foreign capital investment, and the mobility of labor that increases eventually connectivity between ASEAN and China through the BRI. The Asia Development Bank (ADB) estimated that the total infrastructure investment needs in ASEAN could be

15 See https://asean.org/asean/about-asean/overview/, 2021. 
between USD 2.8 trillion as a baseline estimate and USD 3.1 trillion as a climate-adjusted estimate from 2016 to 2030 . The infrastructure investment contributed to increasing the amount of ASEAN trade from USD 4 trillion in 2010 to USD 5 trillion in $2017^{16}$. The total trade is expected to increase further as ASEAN grows from the sixth largest economy in the world in 2017 to the fourth largest economy in the world by 2050 with an expected average economic growth of 5.25 percent between 2016 and $2020^{17}$.

The connectivity of Chinese supply chain has risen with the BRI participating nations over the past decade in general, and with ASEAN member nations in particular. It reflects a continuation of outsourcing to China from high-income economies in the region such as Singapore and Malaysia, while Chinese firms also outsource low value added processes to the region's low-income economies such as Cambodia and Laos. By intensifying this process, many ASEAN member nations such as Singapore, Vietnam, Thailand, Malaysia, Cambodia, and Myanmar become among the top ten most connected to China via trade. China deepens trade relations with ASEAN economies by completing the ASEAN-China Free Trade Agreement (ACFTA) in 2010 that was signed by ASEAN as the first FTA with external parties. ASEAN and China decided to upgrade the ACFTA in 2014 as a part of BRI that came into effect in 2016. Since then trade and investment flows have accelerated ${ }^{18}$ (See table 1).

Among ASEAN member nations, low cost economies such as Cam -06 tab Chul CD-Especial 3 bodia, Myanmar, and Vietnam outsourcing from China have been benefited by increasing their economic growth in foods, textiles, electrical and machinery assembly. China's increasingly cha -06 tab Chul CD-Especial 3 llenging demographics and rapidly rising wage costs have pushed such a trade connectivity that will be deepened in the years ahead. At the same time, higher income economies in ASEAN, such as Malaysia and Singapore play key roles in upgrading China's ma -06 tab Chul CD-Especial 3 nufacturing sectors. Malaysia supplies microchip production, while Singapore exports chemicals, plastics, and rubber pro -06 tab Chul CD-Especial 3 ducts that contributes to China's manufacturing shift into higher value added sectors.

16 ADB, op. cit. (2017): 5-20.

17 The ASEAN Secretariat, ASEAN Statistical Yearbook, 2018 (Jakarta: ASEAN Secretariat, 2018).

18 Yan, J., The Belt and Road Initiative in Southeast Asia, in CIMB ASEAN Research Institute (ed.) China's Belt and Road Initiative (BRI) and Southeast Asia (Kuala Lumpur: CIMB CARI, 2018): 4-9. 


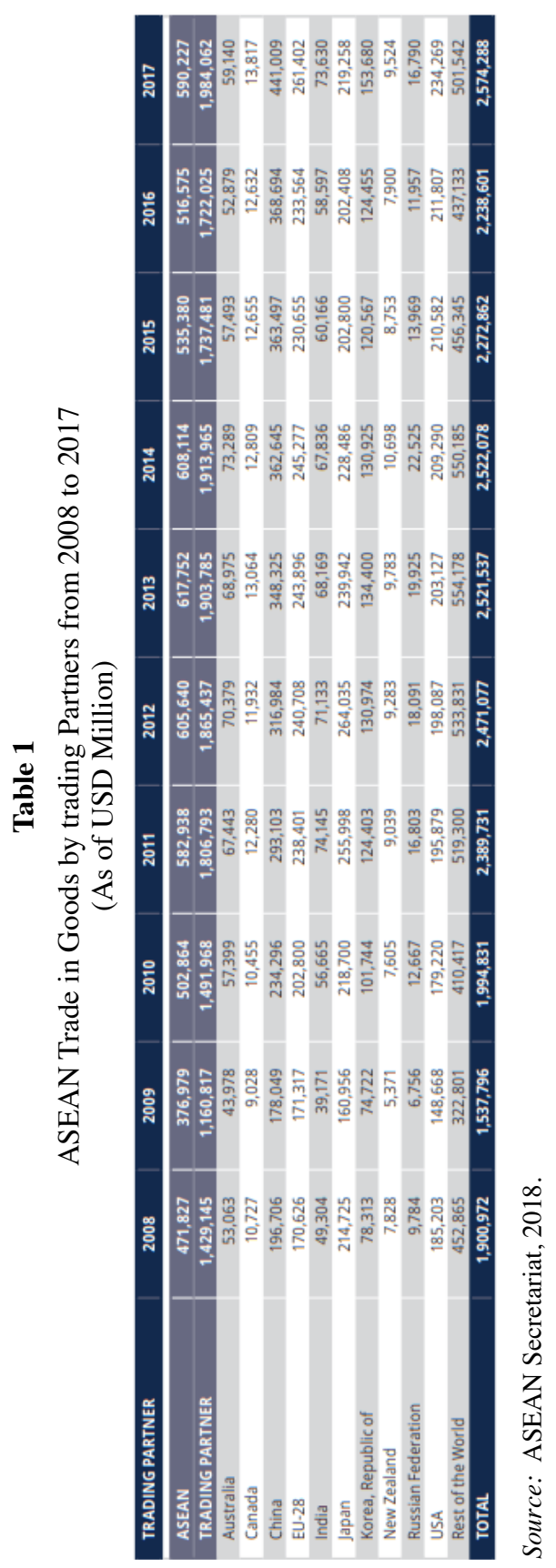

Cuadernos Europeos de Deusto 


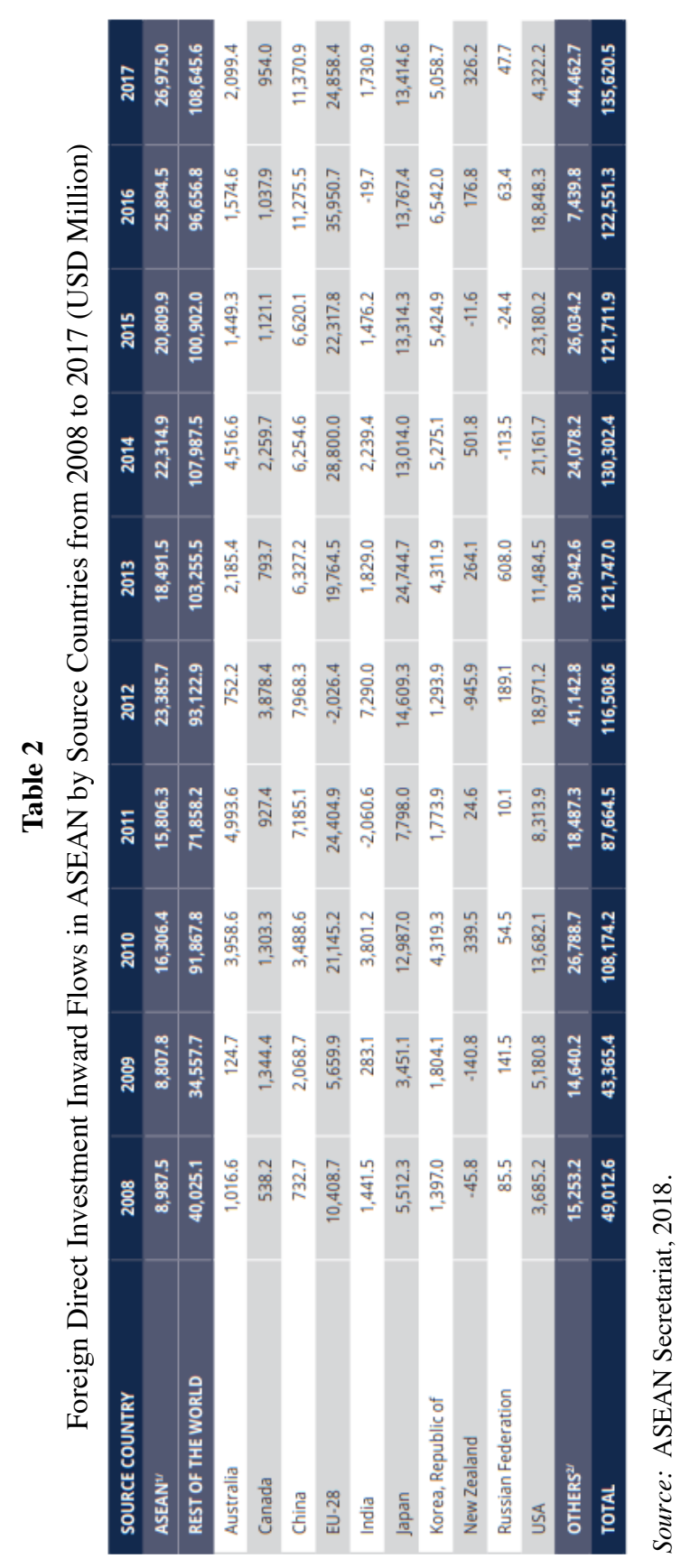


The Chinese investment composed of direct investment, portfolio investment, and official investment in ASEAN increased rapidly since 2008. Before the year of 2013, Chinese investment was focused on commodity exporting economies for securing raw materials in the region that was the priority of Chinese investment strategy for domestic industrial activity. Since 2014, Chinese investment with high value added economies has become more important than accessing raw materials. Therefore, China started increasingly to focus on accessing high technology that made China to become an outbound investor and net capital investor since 2016. As a result, China invested the third largest amount of USD 11.4 billion in 2017 after the EU and Japan in the region. The rapidly increasing Chinese investment in the region is not entirely triggered by the BRI, but it reflexes the current stage of Chinese economic development cycle ${ }^{19}$ (See table 2).

According to the report of Industrial and Commercial Bank of China (ICBC) Standard and Oxford Economics, there are over 1,100 investment projects in 88 original and new partner countries announced and underway since 2013 that is worth more than USD 750 billion in the BRI projects although the total investment varies from scholars. Popular estimates for Chinese investment to the BRI range from USD 1 trillion to 8 trillion due to the undefined scope of the initiative and limited data availability of the projects. These investment projects include Nigeria, Russia, Saudi Arabia, Indonesia, Bangladesh, Cambodia, Laos PDR, and Ethiopia, where construction projects have been announced, underway or completed since $2013^{20}$. These nations possess mainly two characteristics that are either geographically close to China either with significant natural resource reserves or with the finances available to contract Chinese engineering companies to build their domestic infrastructure. Among the top 10 investment hosting countries, there are four ASEAN member nations and two South Asia countries. It indicates the importance of ASEAN and South Asia for the BRI ${ }^{21}$ (See figure 1).

Despite the fact, it covers over 72 countries in the world listed in the 2015 Official Action Plan and includes infrastructure construction in the BRI countries with Chinese involvement in financing, construction, operating capacity, and direct investment through merger and acquisitions ${ }^{22}$. The World

19 The ASEAN Secretariat, op. cit. (2018): 2-5.

${ }^{20}$ ICBC Standard Bank and Oxford Economics, Belt and Road Interim Report: Tracking Evolving Scope, Discovering Expanding Opportunities (London: ICBC Standard Bank, 2018): 5-10.

${ }^{21}$ Hillman, J., How Big is China's Belt and Road? (2018) https://www.csis.org/analysis/ how-bigchinas-belt-and-road.

22 Bandiera, L. and Tsiropoulos, V., A Framework to Access Debt Sustainability and Fiscal Risks under the Belt and Road Initiative, Unpublished Working Paper, World Bank (Washington D. C.: The World Bank, 2019): 1-10. 
Bank estimates that the total investment of the BRI accounts for USD 575, including projects in all sectors in implementation phase and planned ${ }^{23}$.

\section{Figure 1}

Top 10 BRI Investment Hosting Countries based on Announced, in Progress or Completed Projects since 2013

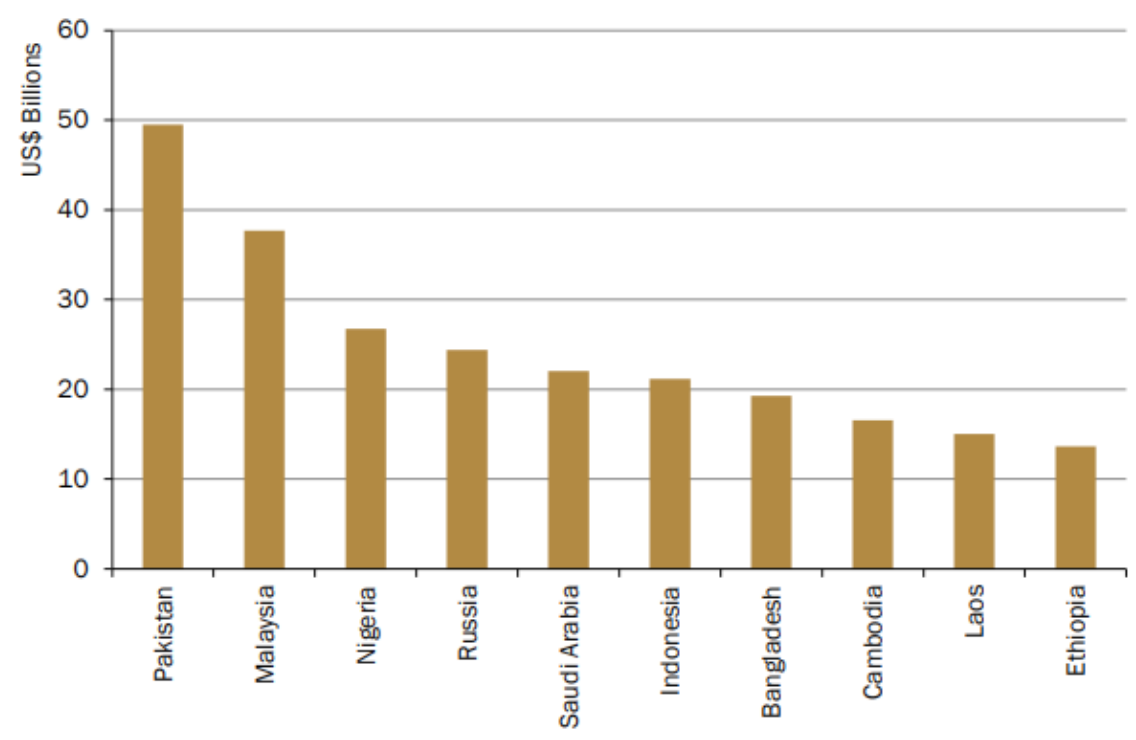

Source: ICBC Standard \& Oxford Economics, 2018.

ICBC Standard Bank and Oxford Economics urged that the transport and logistics sector has been the largest recipient of funds for the BRI projects worth over USD 330 billion announced in progress or completed since 2013. The energy sector is the second largest at USD 266 billion. However, the World Bank reported that the largest investment in the BRI project is the energy and electric power worth over USD 264 billion, and the transportation and shipping is the second largest sector worth USD 144 billion in 70 corridors economies in $2019^{24}$. The energy and transport sectors absorb 71 percent of the total BRI investment. Among the BRI investment, East Asia and the Pacific Region nations receive 34 percent of

${ }^{23}$ The World Bank, Belt and Road Economics: Opportunities and Risks of Transport Corridors (Washington D. C.: The World Bank, 2019): 15-19.

${ }^{24}$ ICBC Standard Bank \& Oxford Economics, op. cit. (2018): 11-18. 
the total investment, and Europe Central Asia are the second largest regions to receive the investment with 32 percent. South Asia and Middle East and North Africa follow with 19 percent and 13 percent respectively. Finally, Sub-Saharan African share accounts only for two percent ${ }^{25}$ (See fig. $2 \& 3$ ).

\section{Figure 2}

Industrial Sectors of BRI Investments in Percentage Shares of USD 575 Billion (As of 2019,\%)

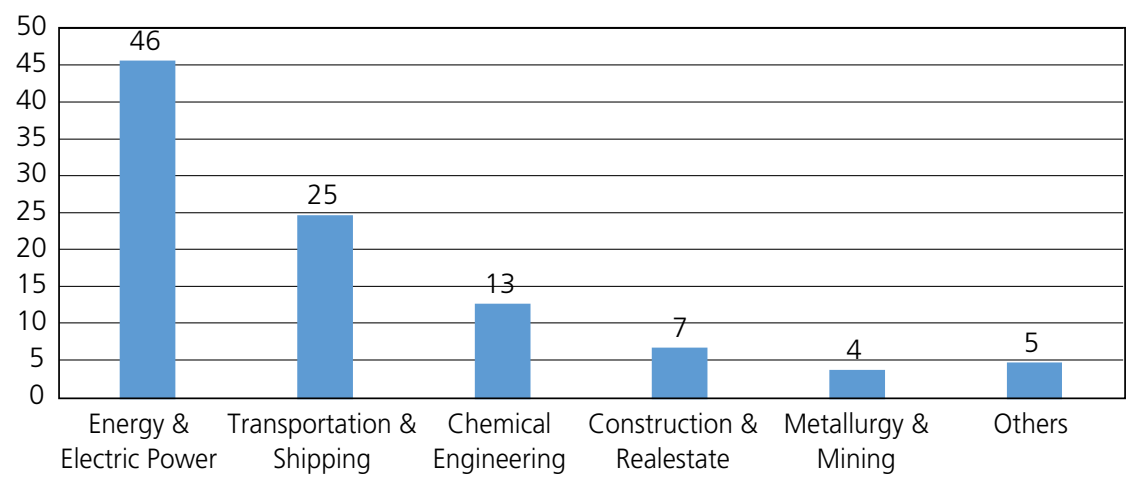

Source: The World Bank, 2019.

\section{Figure 3}

Regions of BRI Investments in Shares of USD 575 Billion

(As of 2019,\%)

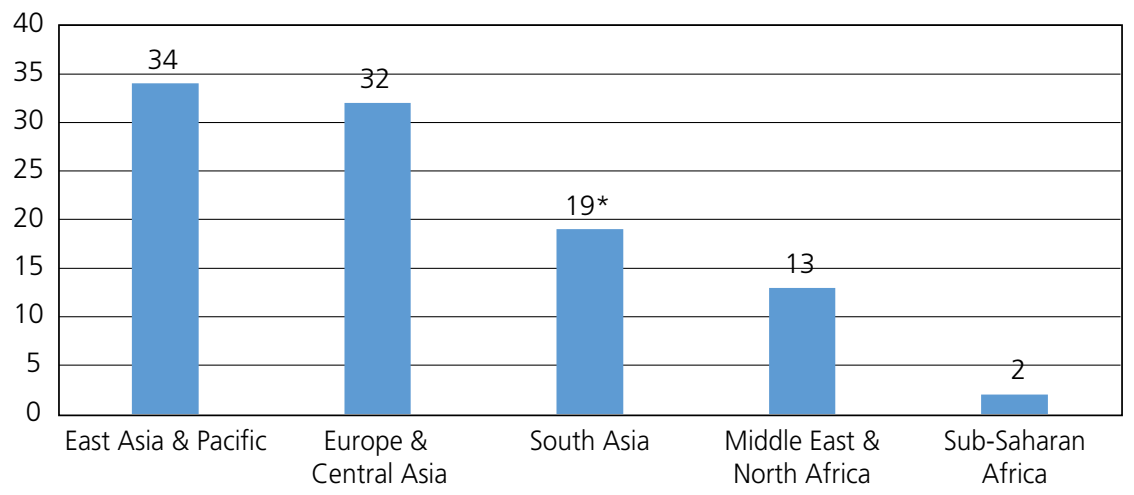

Source: The World Bank, 2019.

25 The World Bank, op. cit. (2019): 20-23. 
Most of the BRI projects in ASEAN member nations started since 2013 and involved mainly transport infrastructures and energy sectors such as railways, roads and power plants. There are 19 BRI projects that were under construction between 2013 and 2018 in ASEAN member nations. These projects were carried by the Chinese investment in Brunei with one, Cambodia with five, Indonesia with five, Lao PDR with three, Malaysia with three, Singapore with one and Thailand with one. One BRI project in Myanmar was also planned, but not clear when it will be launched. Among these projects, the largest 10 projects started in 2013, two in Malaysia, two in Thailand, one in Brunei, Cambodia, Laos PDR, Indonesia, Myanmar, and Singapore (See table 3).

\section{Table 3}

The 10 largest BRI Projects in ASEAN

\begin{tabular}{|c|c|c|c|c|c|c|}
\hline Rank & Year & Chinese Entity / Project & Cost USS & Sector & $\begin{array}{l}\text { Subsector } \\
\text { (where } \\
\text { applicable) }\end{array}$ & $\begin{array}{l}\text { Country of } \\
\text { investment }\end{array}$ \\
\hline 1 & 2017 & $\begin{array}{l}\text { Kuala Lumpur-Kota Bahru } \\
\text { Rail (Construction) }\end{array}$ & $14,300,000,000$ & Transport & Rail & Malaysia \\
\hline 2 & 2013 & $\begin{array}{l}\text { Preah Vihear-Kaoh } \\
\text { Kong Railway }\end{array}$ & $9,600,000,000$ & Transport & Rail & Cambodia \\
\hline 3 & 2017 & $\begin{array}{l}\text { Vanke, Hopu, Hillhouse, } \\
\text { Bank of China }\end{array}$ & $9,060,000,000$ & Logistics & & Singapore \\
\hline 4 & Unclear & $\begin{array}{l}\text { Kyaukpyu Deep Sea } \\
\text { Port (Construction) }\end{array}$ & $7,300,000,000$ & Transport & $\begin{array}{l}\text { Posts/ } \\
\text { Shipping }\end{array}$ & Myanmar \\
\hline 5 & 2015 & China General Nuclear & $5,960,000,000$ & Energy & & Malaysia \\
\hline 6 & 2016 & $\begin{array}{l}\text { Vientiane-Boten } \\
\text { Railway Project }\end{array}$ & $5,800,000,000$ & Transport & Rail & Laos \\
\hline 7 & 2017 & $\begin{array}{l}\text { Bangkok to Nakhon } \\
\text { Ratchisima High-Speed } \\
\text { Railway (Phase 1) }\end{array}$ & $5,352,905,500$ & Transport & Rail & Thailand \\
\hline 8 & 2013 & Zhejiang Hengyi & $3,440,000,000$ & Energy & Oil & Brunei \\
\hline 9 & 2017 & China Railway Engineering & $3,190,000,000$ & Transport & Rail & Indonesia \\
\hline 10 & 2017 & $\begin{array}{l}\text { China Railway } \\
\text { Construction, China } \\
\text { Railway Engineering }\end{array}$ & $2,690,000,000$ & Transport & Rail & Thailand \\
\hline
\end{tabular}

Source: ICBC Standard Bank\& Oxford Economics, 2018.

However, a few BRI related projects are under review, either to be cancelled or re-negotiated. These are the Jakarta Monorail Project in Indonesia and the ECRL Project in Malaysia. The latter has been subject to pending further negotiations between China and the new Malaysian government 
since 2018. Moreover, the Jakarta-Bandung Railway Project is also under threat because the China Development Bank delayed to release the loan ${ }^{26}$.

ASEAN's strategies to cooperate with the BRI are to realize the following goals:

Firstly, ASEAN member nations understand that Chinese investment in the BRI projects could provide opportunities to overcome the problem of inadequate infrastructure in the region that is a major obstacle for the further ASEAN's economic growth in a short term and a long term. Additionally, the BRI projects linked to internationally sourced financing including from China could draw investments into productive sectors such as manufacturing, energy, and services in ASEAN member nations.

Secondly, ASEAN member nations hosting the BRI projects are keen to reduce the trade imbalance with China. Until 2018, trade in goods and services between the two parties was in China's favor. However, ASEAN member nations hope that they could increase their exports to China due to the better market access after completing the BRI projects.

Last, but not least, ASEAN hosting countries to the BRI expect increasing exports into China and Europe connecting the continental ASEAN member nations to Central Asia, Russia, and Eastern Europe that could contribute to generating a further economic growth in the region ${ }^{27}$.

\section{III.II. Chinese roles and strategies of the BRI}

In March 2015, the Chinese government issues an action plan describing main objectives of the BRI. In the plan, the BRI participating nations represent more than one third of global GDP, nearly two third of world's population, and USD 3 trillion trade between China and BRI countries between 2014 and $2016^{28}$. While infrastructure investment is known as a key aspect of the BRI, China strongly intends that the BRI is much broader in its objectives, encompassing sustainable growth including more balanced regional growth, the upgrading of its industry and economic growth at home and in the participating economies ${ }^{29}$ (See fig. 4).

26 Jusoh, S. (2018) The Impact of BRI on Trade and Investment in ASEAN, in CIMB ASEAN Research Institute (ed.) China's Belt and Road Initiative (BRI) and Southeast Asia (Kuala Lumpur: CIMB CARI, 2018): 10-18, Negara, S. D. and Suryadinata, L., Jakarta-Bandung High Speed Rail Project: Little Progress, Many Challenges, ISEAS Perspective, Issue 2018, 2 (2018), Singapore, 4 Jan.

27 Jusoh, op . cit. (2018): 11-12.

28 OECD, op . cit. (2018).

${ }^{29}$ Hong Kong Shanghai Banking Cooperation (HSBC), Belt, Road and Beyond: Understanding the BRI Opportunity (London: HSBC, 2019). 
Figure 4

A Glance of the BRI (As of 2017)

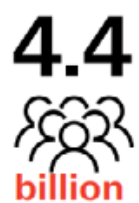

Combined population of allcountries involved in BRI

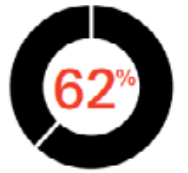

BHI touches 62 percent of the world's population

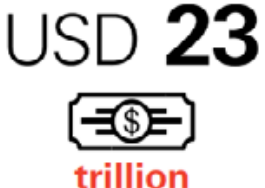

Combined GDP of all countries involved

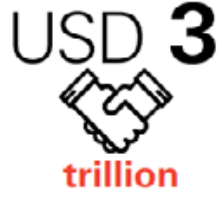

Trade between China and BRI countries between 2014-2016

Source: China Power Project, 2017.

The BRI is a colossal project that aims to improve regional cooperation through better connectivity among countries located in the ancient Silk Road and beyond. It includes the Silk Road Economic Belt for the land and the $21^{\text {st }}$ Century Maritime Silk Road for the sea. At the start, 64 nations participated in the BRI, and the total numbers of participating economies have increased over 100 in different forms. Through the BRI, China needs to ensure not only a shift of excess capacity and less environmentally friendly energy resources to other countries, but also contribute to strengthening sustainable development goals in 2030.

The BRI targets specific objectives focusing mainly on an economic growth through the connectivity between China and participating economies in the project ${ }^{30}$. The connectivity is based on facilitating trade and investment, and thereby economic and social development of neighboring countries. Additionally, it supports strategically security of energy, resources and foods, while China takes a regional leadership with its most important neighbors. Accordingly, the BRI has a broad scope including cultural, economic, and strategic connectivity ${ }^{31}$. The strategic objectives of the BRI are set clearly in Chapter 51 and other parts of the $13^{\text {th }}$ Five-Year Plan. These are as follows: to increase trade and investment in the BRI, to build free trade zones along the Silk Road, to enhance financial cooperation in the region to fund infrastructure, to gain access to natural resources, to strengthen transport infrastructure in the BRI corridors, and to deepen cultural exchanges in the region ${ }^{32}$.

30 People's Republic of China, 13th Five-Year Plan on National Economic and Social Development (2016) ,http://en.ndrc.gov.cn/newsrelease/201612/P020161207645765233498. pdf., accessed on 22 Jan. 2021.

31 Cai, P., Understanding China's Belt and Road Initiative (Sydney: Lowy Institute, 2017).

32 OECD, op . cit. (2018). 
In order to meet the six strategic objectives, the BRI designed the six economic corridors based on China's development model that are ChinaMongolia-Russia, New Eurasia Land Bridge, China-Central Asia-West Asia, China-Pakistan, Bangladesh-China-India-Myanmar, and China-Indochina Peninsula Economic Corridors ${ }^{33}$. Among these, the Bangladesh-China-IndiaMyanmar Economic Corridor seems to develop more slowly than expected due to mistrust over security issues between China and India. In the BRI, infrastructure investment along the Belt and Road is concerned with the six economic corridors covering a large energy and resource rich areas in the world. Furthermore, the BRI is keen to link up road and rail connections with global ports that is very essential to function the maritime Silk Road properly. By doing that, the BRI connects China to Central Asia, East Asia, Southeast Asia, South Asia, West Asia, Europe, and African continent ${ }^{34}$ (See fig. 5).

\section{Figure 5}

Map of One Belt and One Road

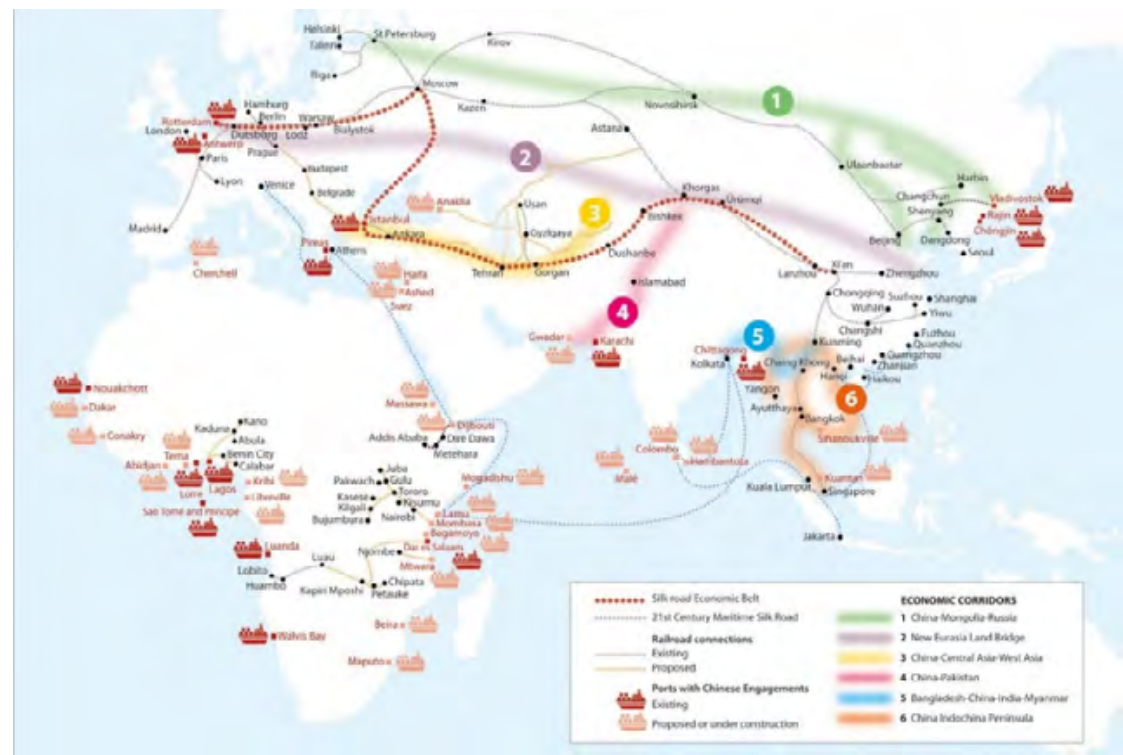

Source: OECD Research from Multiple Sources, 2018.

33 OECD, op . cit. (2018).

${ }^{34}$ Patil, S., OBOR and India's Security Concerns (2015): https://www.gatewayhouse.in/ security-implications-of-chinas-transnational-corridors/, accessed on 22 Jan. 2021. 
Primary functions of the BRI economic corridors and the maritime Silk Road are based on how China achieves its strategic objectives whether that be through improving access to export markets, raw materials or manufactured goods. In order to improve access to export markets, the ChinaPakistan Economic Corridor, the New Eurasian Land Bridge, and the New Maritime Silk Road can facilitate smooth trade links between China and some of the world's largest markets with shorter lead-time and fewer frictions. Secondly, the China-Mongolia-Russia Economic Corridor, the China-Central Asia-West Asia Economic Corridor play roles in accessing to raw materials due to their geographical proximity and a large quantity of raw materials in the regions. Last, but not least, the China-India-Bangladesh-Myanmar Economic Corridor and the Indochina Peninsula Economic Corridor are focused on improving access to supply chains for Chinese manufacturing sectors. China needs low wage economies for outsourcing additional manufacturing processes with improved transport links because wages increase continuously in China ${ }^{35}$.

In order to connect these strategic economic corridors, China has invested millions of dollars to carry global construction projects mainly for building infrastructure from 2005 and 2018. During the period, the cumulative total amount accounts for USD 480.3 billion in the BRI participating economies. It is around 59 percent of the global total of USD 814.3 billion. Along with the BRI participating economies, Sub-Saharan Africa is the second largest infrastructure investment area with USD 170.7 billion, and the Latin America, the Middle East and North Africa (MENA) as well as the EU, excluding EU economies participating in the BRI follow ${ }^{36}$ (See fig. 6).

Such a massive investment policy for building infrastructure outside China could reduce air pollution and increase the quality of environment because China's new environmental regulations provide cement and metal industries market incentives to move to the west of China and along the Silk Road ${ }^{37}$. Additionally, the policy aims to move old iron and steel capacity out along the Belt and Road in order to strengthen the metal industry focusing on cleaner, high-tech, steel products and metal trading. It was explicitly highlighted by the Premier Minister Li Kequing in the $17^{\text {th }}$ ASEAN Conference. In line with the investment policy, Hebei Province moved the capacity for 5.2 million tons of steel, 5 million tons of cement, and 3 million units of glass abroad in 2017. These will increase to 20 million, 30 million, and 10 million respectively by 2030 . By improving

35 ICBC Standard Bank and Oxford Economics, op. cit. (2018).

36 OECD, op. cit. (2018). (2016)

37 Klay, D. van der, China Shifts Polluting Cement to Tajikistan, China Dialogue, 8 Aug. 
connectivity via the infrastructure investment policy, the BRI has a strong potential to create a solid platform for trade and investment, in which China plays a role as its center ${ }^{38}$.

\section{Figure 6}

Chinese Cumulative Outward Investment in the Construction Sector between 2005 and 2018 (As of USD Million)

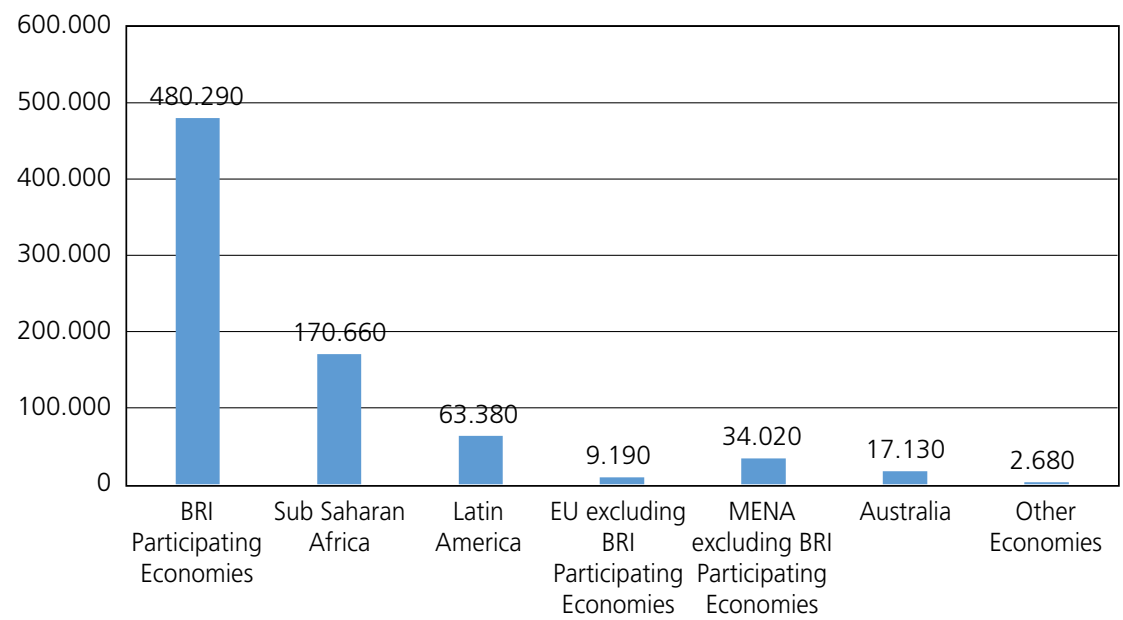

Source: American Enterprise Institute, 2018 and China Global Investment Tracker Database, 2018, Note: 2018 data are until the end of June.

\section{III.III. Financing and risks of the BRI in participating countries}

Chinese investments in the BRI projects since the initiative launch in 2013 were stated officially that it had totaled to USD 60 billion in 2017. Over the ensuing five years, China's total outbound investment could account for between USD 120 billion and UDS 130 billion per year that will reach up to USD 800 billion in total ${ }^{39}$. According to the Chinese State Council, the total funding for the BRI ranges from USD 4 trillion to USD 8 trillion if the BRI is fully implemented. It will be difficult for China's policy and commercial banks to provide the total investment financing on their own so that China needs to seek partnerships wherever possible in

\footnotetext{
38 OECD, op. cit. (2018).

39 HSBC, op . cit. (2019).
} 
order to attract additional financing sources from third party public and foreign private funds ${ }^{40}$.

The share of all infrastructure investment financed by the private sources in emerging markets is estimated between 20 and 25 percent in recent years. The rest share is financed by governments and development banks. However, the share of the infrastructure investment in the BRI financed by private sources accounts less for 10 percent. The BRI is mainly financed by large Chinese financial institutions supported by the Chinese government. These are two policy banks and four state owned commercial banks. The former are the Export-Import Bank of China and China Development Bank. The latter are ICBC, China Construction Bank, Agricultural Bank of China, and Bank of China. Additionally, foreign governments and multilateral development banks (MDBs) finance the BRI less than 10 percent of the total. It is a high challenge for China to generate interests of investment in the BRI from non-Chinese and private sources ${ }^{41}$ (See fig. 7).

\section{Figure 7}

Share of Total Funding for the BRI in Different Financial Sources

(As of $2017, \%$ )

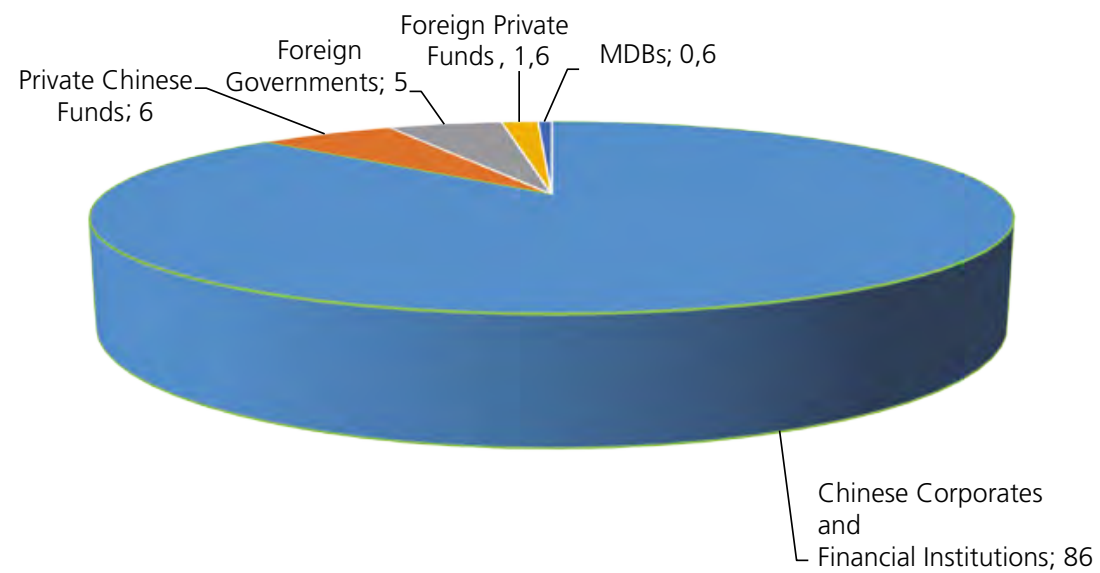

Source: Oxford Economics, 2018.

Among the foreign governments participating in the BRI, Saudi Arabia invests mostly with over USD 12 billion and Hong Kong and Macau

${ }^{40}$ ICBC Standard Bank \& Oxford Economics, op. cit. (2018).

${ }^{41}$ ICBC Standard Bank \& Oxford Economics, op. cit. (2018). 
follow. Among the MDBs, the ADB is the largest investor with USD 1.8 billion. After the ADB, the Inter-American Development Bank (IADB) invests around USD 1 billion and EU MDBs' investments are rather very marginal. Among the ASEAN countries, Malaysia is only one nation to invest with over USD 1 billion. These nations and MDBs invest mostly in building the infrastructures such as roads, rails, and power stations. They are able to provide either mature financial markets or sovereign wealth funds that can finance infrastructure projects within their borders. At the same time, these nations can also attract inward BRI investment and even explore the BRI opportunities in the third party economies ${ }^{42}$ (See fig. 8).

\section{Figure 8}

Foreign governments and MDBs Investing in BRI Projects from 2013 to 2017

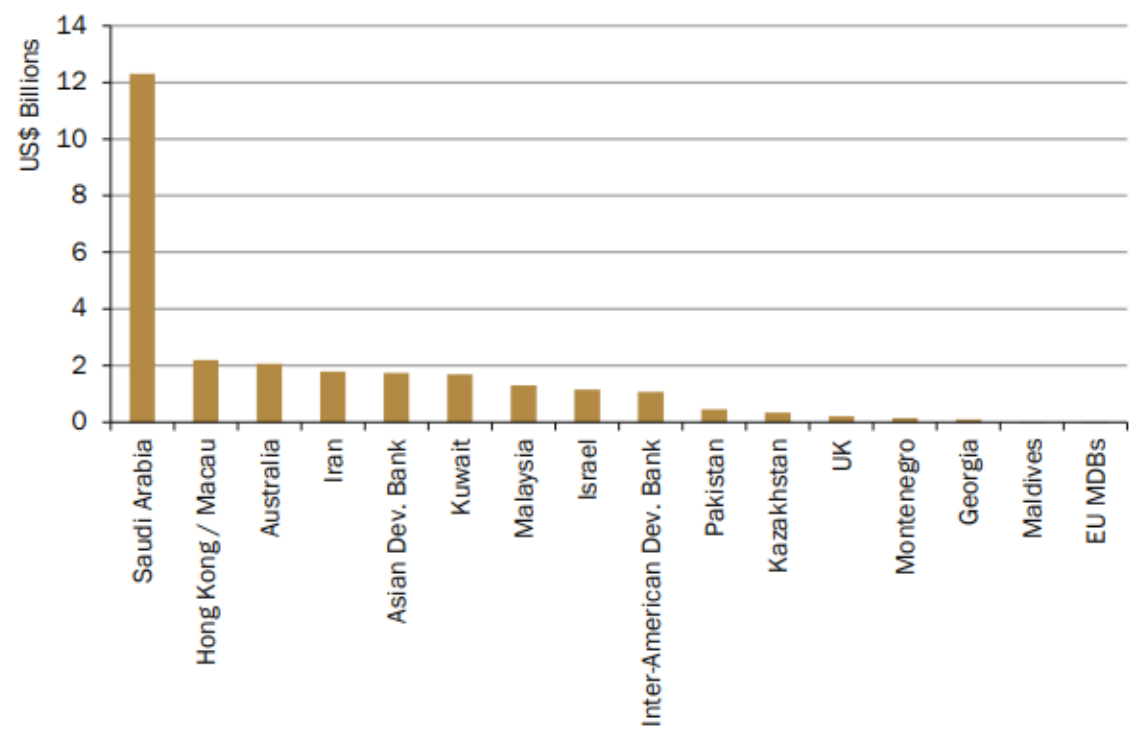

Source: Oxford Economics, 2018.

Among the six largest Chinese financial institutions, the Industrial and Commercial Bank of China (ICBC) invested the largest amount with USD 159 billion. China Development Bank, Bank of China, and China Exim Bank follow with USD 110 billion, 100 billion and USD 80 billion respectively. Besides the six largest financial institution, the Chinese go-

${ }^{42}$ ICBC Standard Bank \& Oxford Economics, op. cit. (2018). 
vernment established Silk Road Fund, New Development Bank (NDB), and Asia Infrastructure Investment Bank (AIIB) in order to finance the BRI projects. Moreover, China Export and Credit Insurance Corporation (SINOSURE) signed a cooperation agreement on the BRI with the ICBC in 2015 in order to focus on supporting projects in regions along the BRI area. It guaranteed USD 570.56 billion for China's export, investment and contracting projects in the countries along the BRI area. All Chinese financial institutions do have different features how to finance the BRI projects $^{43}$ (See table 4 ).

It is no doubt that the BRI projects could have high potential to accelerate the economic integration and development in the participating countries. However, at the same time, the large cost of the BRI projects raises concerns about the debt sustainability in some countries of the BRI area due to the poor information about the investment and financing terms of the BRI projects, and the lack of a comprehensive fiscal framework ${ }^{44}$. Under the BRI, investment projects are mainly structured as public investments or as public-private partnerships (PPPs) with one Chinese stateowned enterprise (SOE). Financing measures use to be foreign currency denominated debt to a government, SOE, or private entity. Interest costs of Chinese loans are on average more favorable than borrowing on market terms that are mostly concessional with fixed interest rates of two percent in median, a grace period of six years, and a maturity of 20 years. However, these are not most favorable for low-income developing countries (LIDCs) such as Laos PDR, Cambodia etc. A growing share of loans to emerging market economies (EMEs) with flexible interest rates benchmarked to six month LIBOR rate, a grace period between 3 and 5 years, and a maturity period between 12 and 18 years. Interest rates from Chinese lenders to LIDCs are on average more favorable than to EMEs, but remain higher than those available from other creditors at low and moderate risk of debt distress. Moreover, Chinese loans use to be associated with other economic costs arising from collateralization that could burden LIDCs and EMEs and increase risks of their economies ${ }^{45}$.

43 OECD, op. cit. (2018).

44 The World Bank, op. cit. (2019).

45 Bandiera, L. and Tsiropoulos, V., op. cit. (2019). 


\section{Table 4}

Chinese Major Financial Institutions for the BRI Projects

\begin{tabular}{|c|c|c|c|}
\hline Institution & Features & $\begin{array}{l}\text { Estimated Exposure } \\
\text { (USD Billion) }\end{array}$ & Project Examples \\
\hline $\begin{array}{l}\text { China Development } \\
\text { Bank }\end{array}$ & $\begin{array}{l}\text { Non-concessional } \\
\text { loans\& credit lines } \\
\text { Concessional loans } \\
\text { Overseas } \\
\text { investment support }\end{array}$ & 110 & $\begin{array}{l}\text { Supporting } \\
400 \text { plus projects } \\
\text { in } 37 \text { nations along } \\
\text { the BRI }\end{array}$ \\
\hline China Exim Bank & $\begin{array}{l}\text { Preferential export } \\
\text { credits tied to } \\
\text { export } \\
\text { Export buyer's \& } \\
\text { seller's credits }\end{array}$ & 80 & $\begin{array}{l}\text { Supporting } \\
1,000 \text { plus projects } \\
\text { in } 49 \text { nations along } \\
\text { the BRI }\end{array}$ \\
\hline $\begin{array}{l}\text { Agricultural } \\
\text { Development Bank } \\
\text { of China }\end{array}$ & $\begin{array}{l}\text { Overseas } \\
\text { investment support } \\
\text { tied to exports }\end{array}$ & & $\begin{array}{l}\text { Supporting Silk } \\
\text { Road Fund and for } \\
\text { Chinese companies }\end{array}$ \\
\hline $\begin{array}{l}\text { Industrial and } \\
\text { Commercial Bank } \\
\text { of China }\end{array}$ & $\begin{array}{l}\text { Non-concessionary } \\
\text { loans }\end{array}$ & 159 & $\begin{array}{l}212 \text { BRI related } \\
\text { projects }\end{array}$ \\
\hline Bank of China & $\begin{array}{l}\text { Non-concessionary } \\
\text { loans }\end{array}$ & 100 & $\begin{array}{l}\text { Various BRI related } \\
\text { project loans }\end{array}$ \\
\hline Silk Road Fund & $\begin{array}{l}\text { All BRI related } \\
\text { projects }\end{array}$ & 40 & $\begin{array}{l}\text { Infrastructure } \\
\text { projects in energy } \\
\text { sector }\end{array}$ \\
\hline $\begin{array}{l}\text { China Construction } \\
\text { Bank }\end{array}$ & $\begin{array}{l}\text { Contributing to BRI } \\
\text { related projects }\end{array}$ & 10 & MofCom states \\
\hline $\begin{array}{l}\text { New Development } \\
\text { Bank (NDB) }\end{array}$ & BRI related projects & 1.261 & $\begin{array}{l}\text { Loans in } \\
\text { infrastructure sector }\end{array}$ \\
\hline $\begin{array}{l}\text { China Export and } \\
\text { Credit Insurance } \\
\text { Corporation }\end{array}$ & & 570.56 & $\begin{array}{l}\text { Guarantee for } \\
\text { China's export, } \\
\text { investment and } \\
\text { contracting projects } \\
\text { in BRI area }\end{array}$ \\
\hline $\begin{array}{l}\text { Asia Infrastructure } \\
\text { Investment Bank } \\
\text { (AIIB) }\end{array}$ & $\begin{array}{l}\text { Not BRI related } \\
\text { projects (China } \\
36 \% \text { voting) }\end{array}$ & 2.33 & $\begin{array}{l}\text { Nine infrastructure } \\
\text { projects along the } \\
\text { BRI area }\end{array}$ \\
\hline
\end{tabular}

Source: Chinese Academy et al., 2017; US-China ESRC, 2017. 


\section{Analysis on the BRI and possible impacts of the COVID-19 pandemic on the BRI}

\section{IV.I. The BRI in ASEAN and China}

It is no doubt that trade and Foreign Direct Investments (FDI) contribute to close interactions between nations that generate an economic growth in a region. It has also applied to the economic interactions between ASEAN and China, and it has strengthened with the BRI. Since the BRI officially started in 2013, the China's trade volume with ASEAN had increased rapidly until 2017 compared with other major trading partners to ASEAN. China had become the largest trade partner to ASEAN since 2010. The trade volume between ASEAN and China was nearly twice larger than the trade volume between ASEAN and the EU in 2017, although the EU's FDI in ASEAN was more than double of the Chinese FDI in ASEAN in the same year. It indicates that ASEAN economy has been more integrated with the Chinese economy, and the trade dependency of ASEAN on China has become higher than any other economies in the world (See table 1,2).

While the economic integration between ASEAN and China had been deepen, the trade deficit of ASEAN to China had also increased rapidly particularly from the BRI starting year to $2017^{46}$. It means that the BRI generated more economic benefits to China than to ASEAN in terms of trade balance. At the same time, Chinese trade had linked to the BRI participating economies more closely than Organization for Economic Cooperation and Development (OECD) or other economies ${ }^{47}$ (See table 5 and fig. 9).

In addition to the trade, the BRI infrastructure projects will promise significant benefits for connectivity between ASEAN and China that could boost the bilateral trade between ASEAN and China. With a need for infrastructure investment in the ASEAN member nations of up to USD 210 billion per year to 2030, the potential investment from China via the BRI could contribute to a significant increase of the global competitiveness in the region as a whole and some competitive emerging market economies such as Malaysia, Thailand, and Vietnam in particular ${ }^{48}$.

\footnotetext{
46 ASEAN Secretariat, op. cit. (2018).

${ }^{47}$ OECD, op. cit. (2018).

48 ADB, op. cit. (2017), HSBC, op. cit. (2019).
} 


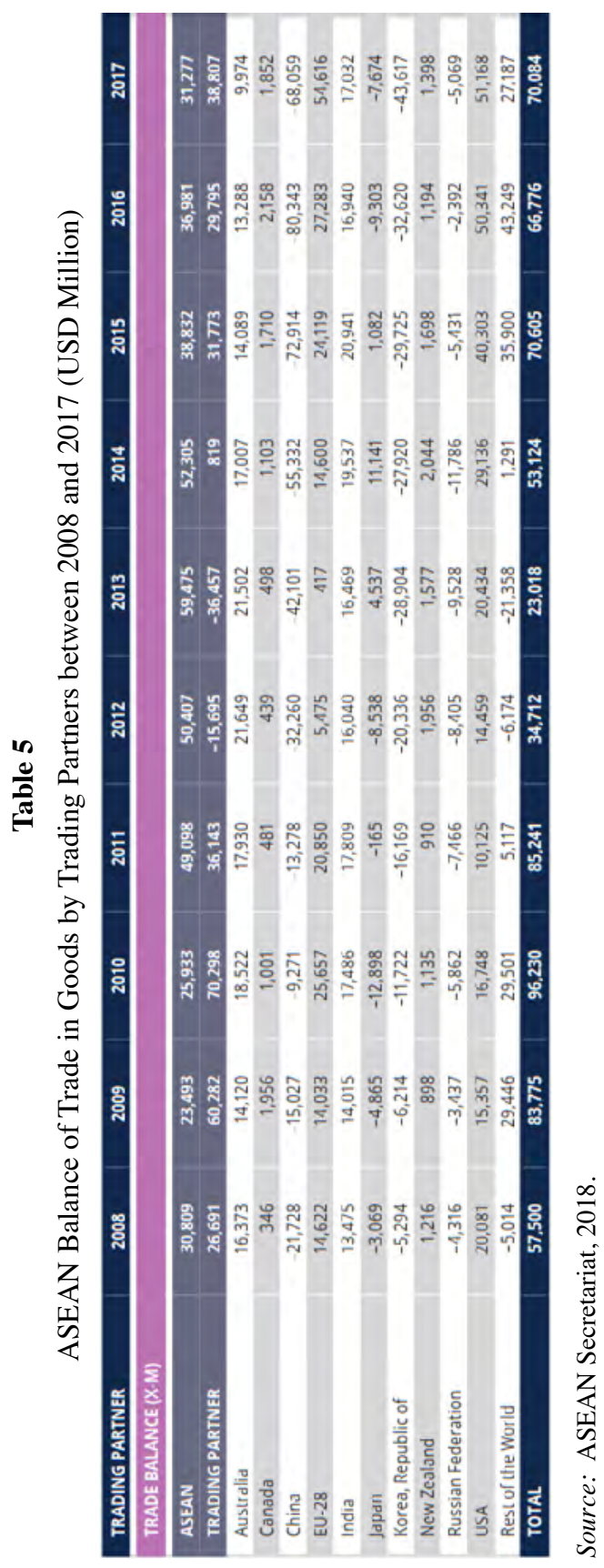

Cuadernos Europeos de Deusto 


\section{Figure 9}

Chinese Exports to BRI Participating Economies Compared with OECD and Others between 1993 and 2017 (\%)

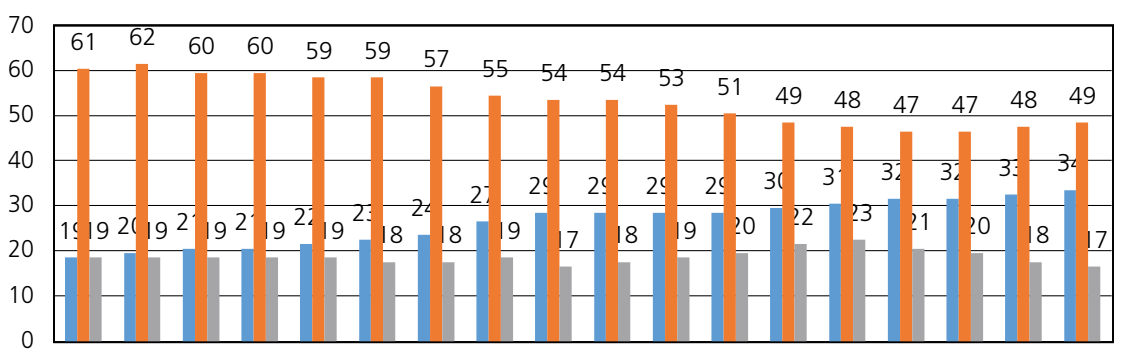

200020012002200320042005200620072008200920102011201220132014201520162017

$$
\begin{aligned}
& \text { - BRI Participating Economies } \\
& \text { - OECD excluding OECD BRI Participating economies } \\
& \text { - Other Economies }
\end{aligned}
$$

Source: Adopted by OECD based on IMF Direction of Trade Database, 2018; OECD Calculations, 2018.

The BRI investments are overwhelmed accumulated mainly in seven countries that are Russian Federation, Pakistan, Malaysia, Indonesia, Bangladesh, Lao PDR, and Cambodia. Among these, four nations are ASEAN countries. In 2017, the median BRI investment amounted to under six percent of GDP in the BRI participating economies. In fact, it is not large compared to investment needs of many developing countries. However, the BRI investments in some ASEAN countries such as Lao PDR, Cambodia, and Malaysia are accrued to over 20 percent of their GDP. Particularly, its ratio in Lao PDR and Cambodia increased over 140 percent and 50 percent respectively. As a result, Lao PDR and Cambodia face a high risk of debt distress, while Malaysia and the rest of ASEAN member nations have medium risk and low risk of debt distress respectively. Countries with vulnerable debt situations such as high and medium risks of debt distress use to have very limited fiscal space to receive new loans and need to receive the BRI debt financing ${ }^{49}$ (See fig. 10).

Additionally, the BRI projects in ASEAN face local residents' protests in Indonesia, corruption allegations in Malaysia, financing and labor conflicts in Thailand, questions for national interests in Laos PDR, environmental protection problems in Indonesia, Malaysia, and Thailand etc. These are based on social, economic, labor, environment areas com-

49 The World Bank, op. cit. (2019) 
prehensively in ASEAN member nations that hinders the BRI projects to be completed fully ${ }^{50}$ (Evers \&Menkhoff, 2018).

\section{Figure 10}

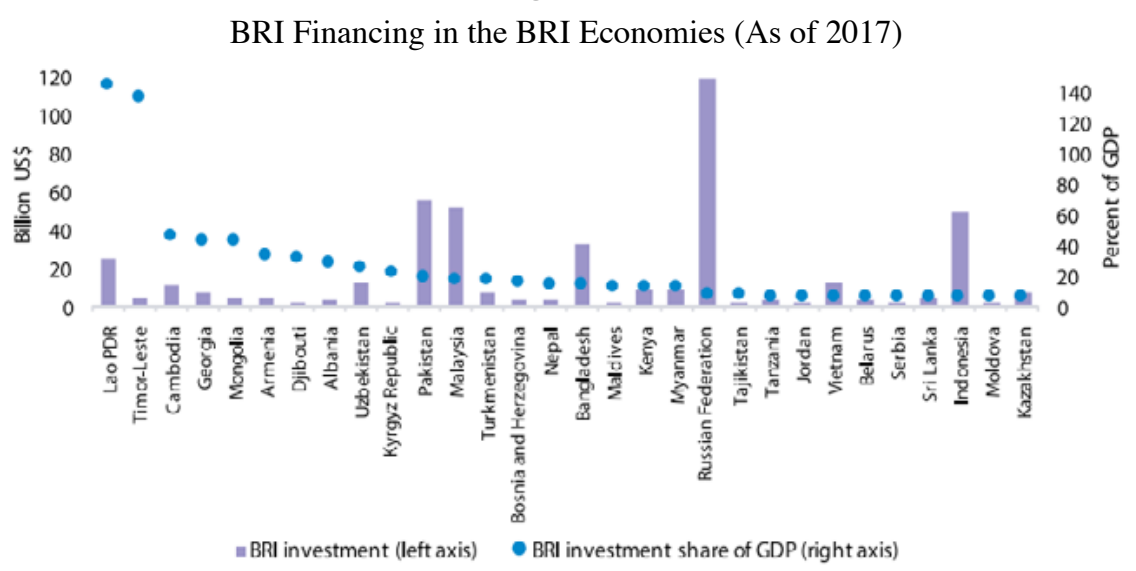

Source: Adopted by The World Bank based on WIND Database and World Development Indicators, 2019.

\section{IV.II. Possible impacts of the COVID-19 pandemic on the BRI}

Since January 2020, the world has experienced the COVID-19 Pandemic and no one can expect exactly when it will be over completely. The pandemic caused the lockdown in many nations including China, around the world that has affected their national economies and the global economy severely. Particularly, it has affected manufacturing, services, supply chains, and movement of people and goods. China has mobilized its resources to manage the containment of the virus and seems to control the pandemic in June 2020, although the small numbers of new patient have been detected within the nation continuously. At the same time, however, it needs to balance challenges to Chinese liquidity and the general economic downturn. Under such a circumstance, the BRI activity will also be affected both in the near and long term future ${ }^{51}$.

50 Evers, H-D and Menkhoff, T., China's Belt and Road Initiative and ASEAN's Maritme Clusters, Southeast Asian Social Science Review, 3:2 (2018): 8-29.

51 Boo, B-C, David, M., Ruan, Z. and Simpfendorfer, B., Understanding How COVID-19 Alters BRI (2020): https://www.bakermckenzie.com/-/media/files/insight/publications/2020/03/covid19-bri-short-report.pdf?la=en, accessed on 18July 2021. 
Given the long term economic forecast, the global economic growth is projected by International Monetary Fund (IMF), the World Bank, OECD at $-4.9,-6.0$, and -5.2 percent in 2020 respectively. It expects a deep downturn in 2020 and a sluggish turnaround in 2021. In the baseline, the global economy is expected to slow down until the second quarter of 2020 and starts to recover thereafter. Among the major economies, China is expected to recover faster than any other economies, while the advanced economies could grow until the end of 2021 to the lower level than that of 2019. Although the global economy recovers fast in the second half of 2020, it will generate about three percent growth in 2021, but it will slow down again up to one percent till $2024^{52}$ (See fig. 11, 12).

Figure 11

World GDP in Quarters (As of 2019 2021, 2019 Q1 = 100)
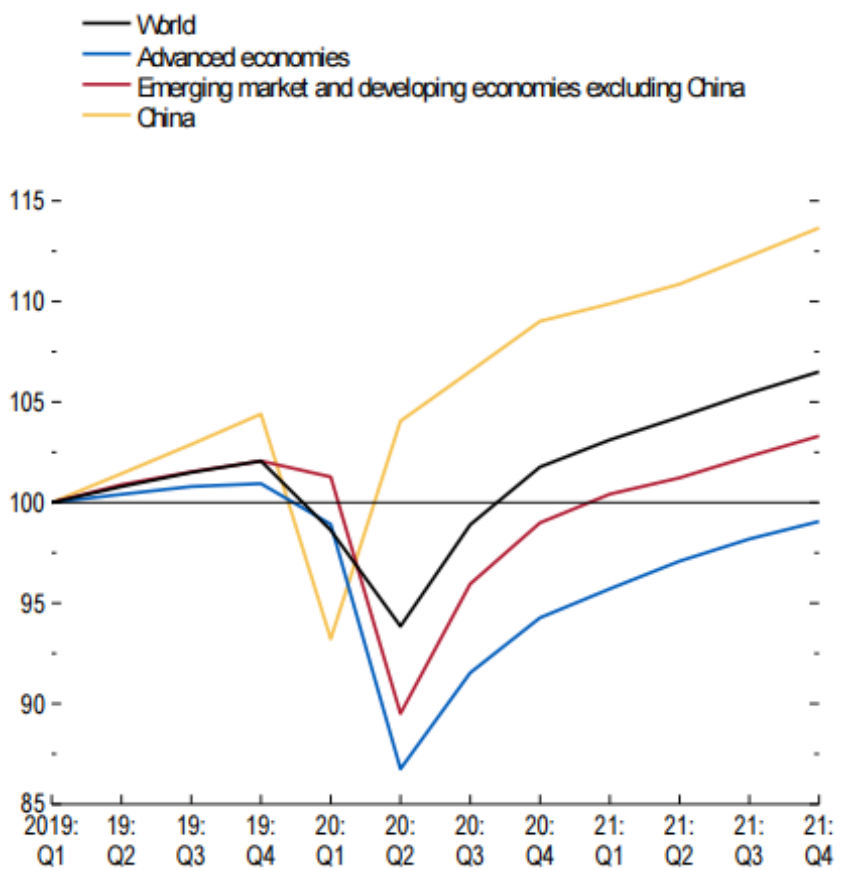

Source: IMF, 2020.

52 International Monetary Fund (IMF), World Economic Outlook Update, June (Washington D. C.: IMF, 2020), The World Bank, Global Economic Prospects, June, Washington D. C.: The World Bank, 2020), OECD, Economic Outlook, June (2020): http:// www .oecd.org/economic-outlook/june-2020/, accessed on 19 July 2021. 


\section{Figure 12}

Alternative Scenarios of Global Economic Growth and Oil Price

(As of 2019 2024)

\section{- Faster Pecovery Starting in the Second Half of 2020 - Second Qutbreak in 2021}

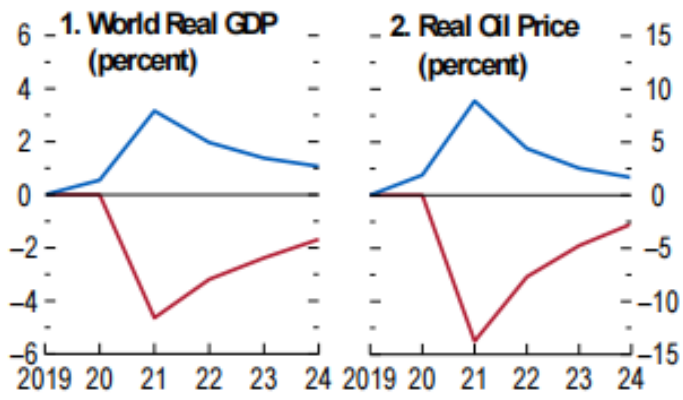

Source: IMF, 2020.

However, the global economy will enter to another deep downturn if the second outbreak in 2021 takes place. It will decline to -5 percent in 2021 , and the oil price will fall up to 15 percent from the price of 2020. In the scenario of the faster recovery, Chinese economy is expected to be the most resilient compare to other major economies and other emerging economies. Therefore, the ASEAN economy could be more dependent on the Chinese economic recovery than other advanced economies. However, in the scenario of the second outbreak, the global economy could generally suffer from the negative growth until 2024 that could affect the BRI in ASEAN severely and negatively in the long term ${ }^{53}$.

The COVID-19 pandemic could change the global supply chains (GSCs) fundamentally. In fact, since 2018, Chinese companies have focused their efforts on the ASEAN markets where supply chain linkages with China are strong and high profits could be generated. Therefore, the COVID-19 pandemic will not hinder the ongoing momentum of Chinese private manufacturers from investing in the ASEAN markets. They will seek to build capacity across the ASEAN markets and hedge against rising risks of supply chain disruptions. It will generate benefits to China's infrastructure investments in ASEAN. Furthermore, Chinese state companies are keen to invest in ports, power, and industrial parks across ASEAN member nations where these projects are aligned with Chinese investment

53 IMF, op. cit. (2020). 
into manufacturing. As a result, it also supports the development of Chinese commercial ecosystem in the region ${ }^{54}$.

\section{Conclusion}

Chinese economy has developed rapidly since its open policy in 1978. It generated a high economic growth with ten percent in average from 1981 to 2010. As a result, China became the second largest economy in 2010, and it is continuously challenging to become the largest economy in the world. Many scholars have discussed whether it is possible for China to take over the economic super power form the USA or not that is still ongoing process and discussion. The answer is rather diverse and depends on what perspectives do scholars have around the world.

Despite the fact, the Chinese government and leadership confirmed its long-term development strategy known as the Belt and Road Initiative (BRI) representing so-called Chinese Dream becoming the global super power in all areas by 2050. The BRI aims to meet the multiple targets such as access to exceed production in cement, glass, and steel, creating further export markets, access to sustainable energy resources, upgrading technological level in domestic industries, solving domestic environmental problems etc. In order to meet these targets, China launched over 1,100 BRI projects in around 100 nations participating in the BRI directly and indirectly and formed the major six economic corridors focusing on their own strategic areas.

Among the six economic corridors, seven of ten ASEAN member nations participate in the China-Indochina Peninsula Economic Corridor and others participate in the Maritime Silk Road. In the China-Indochina Peninsula Economic Corridor, China aims to establish a regional supply chain that provides Chinese economy high tech products from Singapore and Malaysia, as well as outsourcing low-income countries such as Cambodia, Indonesia, Thailand, the Philippines, and Vietnams in order to solve rapidly increasing wages in the Chinese market. In order to establish a well-functioning supply chain in the region, China has invested in the economic corridor heavily along with China-Mongolia-Russia Economic Corridor.

The BRI projects building infrastructure in ASEAN have contributed to increasing connectivity between ASEAN and China that has boosted trade volumes and FDI in the region. However, China and Korea have gained more trade surplus to ASEAN than other ASEAN's major trading partners, while the BRI projects have been launched. It means that the regional supply chain has been established successfully that is more favor to China

${ }^{54}$ Boo et al., op. cit. (2020). 
than to ASEAN. Despite the increasing connectivity created by the BRI, several ASEAN member nations such as Cambodia, Lao PDR, and Malaysia face a high debt risk due to the heavy investment of the BRI that burdens a sustainable national economic growth.

Therefore, these nations need to get a debt financing in order to continue the BRI projects. It indicates that the BRI projects do not impact the participating economies positively automatically, but it is fully dependent on the national development strategies in the participating economies and what kinds of national competitiveness they do have. Among the ASEAN member nations, the Thailand and Vietnamese strategies can be good examples to attract all foreign investments and play roles in manufacturing production hubs, while they keep the BRI projects with low levels in their public debt ratios. The unexpected COVID-19 pandemic will affect the BRI negatively in the short term in the region because it results in a deep downturn in the global economy. However, the ASEAN member nations participating in the BRI could be more dependent on Chinese investments in their infrastructure and manufacturing development projects than other advanced economies because Chinese economic growth amid the COVID-19 pandemic is projected to be the most resilient among the major economies. However, only qualified ASEAN member nations could maximize to gain their national interests.

\section{References}

Asia Development Bank (ADB), Meeting Asia's Infrastructure Needs, 2017, www. adb.org/sites/default/files/publication/227496/special-report-infrastructure.pdf., accessed on 06 Jan. 2021.

Balassa, B., Towards a Theory of Economic Integration, International Review for Social Sciences, 14: 1 (1961): 1-17.

Bandiera, L. and Tsiropoulos, V., A Framework to Access Debt Sustainability and Fiscal Risks under the Belt and Road Initiative, Unpublished Working Paper, World Bank (Washington D. C.: The World Bank, 2019).

Boo, B-C, David, M., Ruan, Z. and Simpfendorfer, B., Understanding How COVID-19 Alters BRI, 2020, https://www.bakermckenzie.com/-/media/files/insight/publications/2020/03/covid19-bri-short-report.pdf?la=en, accessed on 18 July 2021.

Cai, P., Understanding China's Belt and Road Initiative (Sydney: Lowy Institute, 2017).

Chinese Government, China's National Plan on Implementation of the 2030 Agenda for Sustainable Development, 2016, www.fmprc.gov.cn/web/ziliao_674904/ zt_674979/dnzt_674981/qtzt/2030kcxfzyc_686343/P02017041468 9023442403. pdf., accessed on 08 Jan. 2021. 
Dent, C.-M., Networking the Region? The Emergence and Impact of Asia Pacific Bilateral Free Trade Agreement Projects, The Pacific Review, 16:1 (2003):1-28. Evers, H-D and Menkhoff, T. (2018) China's Belt and Road Initiative and ASEAN's Maritme Clusters, Southeast Asian Social Science Review, 3:2 (2018): 8-29.

Hillman, J., How Big is China's Belt and Road? 2018,https://www.csis.org/analysis/how-bigchinas-belt-and-road., accessed on 17 Jan. 2021.

Hong Kong Shanghai Banking Cooperation (HSBC), Belt, Road and Beyond: Understanding the BRI Opportunity (London: HSBC, 2019).

ICBC Standard Bank and Oxford Economics, Belt and Road Interim Report: Tracking Evolving Scope, Discovering Expanding Opportunities (London: ICBC Standard Bank, 2018).

International Monetary Fund (IMF), World Economic Outlook Update, June (Washington D. C.: IMF, 2020).

Jusoh, S., The Impact of BRI on Trade and Investment in ASEAN, in CIMB ASEAN Research Institute (ed.) China's Belt and Road Initiative (BRI) and Southeast Asia (Kuala Lumpur: CIMB CARI, 2018): 10-18.

Katzenstein, P. (1997) Introduction: Asian Regionalism in Comparative Perspective, in Katzenstein, P. \&Shiraishi, T. (eds.) Network Power: Japan and Asia (Ithaca: Cornell University Press, 1997): 1-46.

Katzenstein, P., A world of Regions: Asia and Europe in the American Imperium (Ithaca: Cornell University Press, 2005).

Klay, D. van der, China Shifts Polluting Cement to Tajikistan, China Dialogue, 8 Aug. 2016,www.chinadialogue.net/article/show/single/en/9174-China-shiftspolluting-cement-toTajikistan., accessed on 23 Jan. 2021.

Negara, S. D. and Suryadinata, L., Jakarta-Bandung High Speed Rail Project: Little Progress, Many Challenges, ISEAS Perspective, Issue 2018, No. 2, Singapore, 4 Jan. 2018.

OECD, China's Belt and Road Initiative in the Global Trade, Investment and Finance Landscape, OECD Business and Finance Outlook 2018 (Paris: OECD, 2018).

OECD, Economic Outlook, June 2020,http://www.oecd.org/economic-outlook/ june-2020/, accessed on 19 July 2021.

Patil, S., OBOR and India's Security Concerns, 2015,https://www.gatewayhouse. in/security-implications-of-chinas-transnational-corridors/, accessed on 22 Jan. 2021.

Pempel, T. J. (2010) Soft Balancing, Hedging, and Institutional Darwinism: The Economic Security Nexus and East Asian Regionalism, Journal of East Asian Studies, 10 (2010):209-238.

Pempel, T. J. (2013) Regional Institutions and the Economy-Security Nexus, in The Economy Security Nexus in Northeast Asia, Pempel, T. J. (ed.) (London: Routledge, 2013):146-163.

People's Republic of China, 13th Five-Year Plan on National Economic and Social Development, 2016, http://en.ndrc.gov.cn/newsrelease/201612/ P020161207645765233498.pdf., accessed on 22 Jan. 2021. 
PwC, China's New Silk Route: The Long and Winding Road, 2016,https://www. pwc.com/gx/en/growth-markets-center/assets/pdf/china-new-silk-route.pdf, accessed on 06 Jan. 2021.

The ASEAN Secretariat, ASEAN Statistical Yearbook, 2018 (Jakarta: ASEAN Secretariat, 2018).

The World Bank, Belt and Road Economics: Opportunities and Risks of Transport Corridors (Washington D. C.: The World Bank, 2019).

The World Bank, Global Economic Prospects, June (Washington D. C.: The World Bank, 2020).

Xi, J. P., Secure a Decisive Victory in Building a Moderately Prosperous Society in all Respects and Strive for the Great Success of Socialism with Chinese Characteristics for a New Era, Delivered at the 19th National Congress of the Communist Party of China, 18 October 2017.

Yan, J. (2018) The Belt and Road Initiative in Southeast Asia, in CIMB ASEAN Research Institute (ed.) China's Belt and Road Initiative (BRI) and Southeast Asia (Kuala Lumpur: CIMB CARI, 2018): 4-9.

Zhao, S., Soft versus Structural Regionalism: Organizational Forms of Cooperation in Asia Pacific, The Journal of East Asian Affairs, 12:1 (1998): 96-134.

\section{Websites}

ASEAN Overview, https://asean.org/asean/about-asean/overview/, accessed $10 \mathrm{Ja}$ nuary 2021.

\section{Sobre el autor}

Sang-Chul Park se doctoró en Ciencia Política en Alemania en agosto de 1993 y en Economía en Suecia en 1997. Aprobó el examen de habilitación como catedrático en Ciencia Política en Alemania en 2002 y en Economía en Suecia en septiembre de 2004. Actualmente es Catedrático en la Facultad de Energía y Tecnología basada en el Conocimiento de la Universidad Politécnica de Corea desde 2006. Con anterioridad, trabajó como Profesor Asociado en la Universidad de Gotenburgo en Suecia, desde 2001 a 2003, así como en la Universidad de Okayama, en Japón, desde 2003 a 2006. Ha sido también profesor visitante en la Universidad de Fudan (China, 2014), en el Instituto del Banco Asiático de Desarrollo (Japón 2014), en la Universidad Maria Curie Sklodowska (Polonia, 2016-2021) y en la Universidad Nacional Chiang Mai (Tailandia, 2019). Desde 2012 es el Director de la Revista Asia Pacífico en Estudios sobre la Unión Europea y miembro del Consejo Editorial de la Revista Internacional de Gestión y De- 
sarrollo Empresarial (indexada en Scopus), así como de la Revista Australia-Nueva Zelanda de Estudios Europeos.

\section{About the author}

Sang-Chul Park has received $\mathrm{PhD}$ degrees in political science in Aug. 1993 in Germany and economics in Feb. 1997 in Sweden. He also passed a habilitation examination (full professorship) in political science in Nov. 2002 in Germany as well as a docent evaluation (Swedish habilitation) in economics in Sep. 2004 in Sweden and is currently a Full Professor at Graduate School of Knowledge based Technology and Energy, Korea Polytechnic University since 2006. He served as Associate Professor at Gothenburg University, Sweden from 2001 to 2003 and as Associate Professor at Okayama University, Japan from 2003 to 2006. He also stayed as Visiting Professor at Fudan University, China (2014), Asian Development Bank Institute (ADBI), Japan (2014), Maria Curie Sklodowska University, Poland (2016 2021), and at Chiang Mai National University in Thailand (2019). In 2012, he became the editor in chief of Asia Pacific Journal of EU Studies (APJEUS) and a member of editorial board in International Journal of Innovation and Regional Development (IJIRD) in 2014. In 2016 he serves as associate editor for International Journal of Management and Enterprise Development (IMED) (SCOPUS Journal) and a member of Managing Editorial Board in Australian \& New Zealand Journal of European Studies. 


\section{Derechos de autor}

Los derechos de autor (para la distribución, comunicación pública, reproducción e inclusión en bases de datos de indexación y repositorios institucionales) de esta publicación (Cuadernos Europeos de Deusto, CED) pertenecen a la editorial Universidad de Deusto. El acceso al contenido digital de cualquier número de Cuadernos Europeos de Deusto es gratuito inmediatamente después de su publicación. Los trabajos podrán leerse, descargarse, copiar y difundir en cualquier medio sin fines comerciales y según lo previsto por la ley; sin la previa autorización de la Editorial (Universidad de Deusto) o el autor. Así mismo, los trabajos editados en CED pueden ser publicados con posterioridad en otros medios o revistas, siempre que el autor indique con claridad y en la primera nota a pie de página que el trabajo se publicó por primera vez en CED, con indicación del número, año, páginas y DOI (si procede). Cualquier otro uso de su contenido en cualquier medio o formato, ahora conocido o desarrollado en el futuro, requiere el permiso previo por escrito del titular de los derechos de autor.

\section{Copyright}

Copyright (for distribution, public communication, reproduction and inclusion in indexation databases and institutional repositories) of this publication (Cuadernos Europeos de Deusto, CED) belongs to the publisher University of Deusto. Access to the digital content of any Issue of Cuadernos Europeos de Deusto is free upon its publication. The content can be read, downloaded, copied, and distributed freely in any medium only for non-commercial purposes and in accordance with any applicable copyright legislation, without prior permission from the copyright holder (University of Deusto) or the author. Thus, the content of CED can be subsequently published in other media or journals, as long as the author clearly indicates in the first footnote that the work was published in CED for the first time, indicating the Issue number, year, pages, and DOI (if applicable). Any other use of its content in any medium or format, now known or developed in the future, requires prior written permission of the copyright holder. 